\title{
Utilization of Waste Clay from Boron Production in Bituminous Geosynthetic Barrier (GBR-B) Production as Landfill Liner
}

\author{
Müfide Banar, ${ }^{1}$ Yücel Güney, ${ }^{2}$ Aysun Özkan, ${ }^{1}$ Zerrin Günkaya, ${ }^{1}$ \\ Eren Bayrakc1, ${ }^{3}$ and Derya Ulutaş ${ }^{4}$ \\ ${ }^{1}$ Department of Environmental Engineering, Anadolu University, Iki Eylül Campus, 26555 Eskişehir, Turkey \\ ${ }^{2}$ Anadolu University, Iki Eylül Campus, Research Institute of Earth and Space Sciences, 26555 Eskişehir, Turkey \\ ${ }^{3}$ Department of Civil Engineering, Anadolu University, Iki Eylül Campus, 26555 Eskişehir, Turkey \\ ${ }^{4}$ Department of Chemical Engineering, Anadolu University, Iki Eylül Campus, 26555 Eskişehir, Turkey \\ Correspondence should be addressed to Müfide Banar; mbanar@anadolu.edu.tr
}

Received 9 December 2015; Accepted 28 January 2016

Academic Editor: Matheus Poletto

Copyright (C) 2016 Müfide Banar et al. This is an open access article distributed under the Creative Commons Attribution License, which permits unrestricted use, distribution, and reproduction in any medium, provided the original work is properly cited.

\begin{abstract}
Bituminous geomembranes, one type of geosynthetics, include a hot bituminous mixture with mineral filler and reinforcement. In this study, boron production waste clay (CW) was used as filler to produce a geosynthetic barrier with bentonite, waste tire, and bitumen. Bentonite and waste tires were used as auxiliary fillers and bitumen as the binder. CW/bitumen, CW/bentonite/bitumen, and $\mathrm{CW} /$ waste tire/bitumen mixtures were prepared by using a laboratory mixer at $100^{\circ} \mathrm{C}$. Hot mixtures were extruded into strips by using a lab-scale corotating twin screw extruder $(L / D: 40)$ followed by die casting $(2 \mathrm{~mm} \times 100 \mathrm{~mm})$. Glass fleece or nonwoven polyester was used as reinforcement material and while die casting, both sides of the reinforcement materials were covered with bituminous mixture. Thickness, mass per unit area, tensile strength, elongation at yield, and hydraulic conductivity were used to characterize the geomembranes. Among all geomembranes, nonwoven polyester covered with $30 \%$ bitumen- $70 \%$ boron waste clay mixture (PK-BTM30CW70) was found to be the most promising in terms of structure and mechanical behaviour. After that, consequences of its exposure to distilled water (DW), municipal solid waste landfill leachate (L-MSW), and hazardous waste landfill leachate (L-HW) were examined to use for an innovative impermeable liner on solid waste landfills.
\end{abstract}

\section{Introduction}

Geosynthetic barriers, also known as geomembranes, are defined as a nonporous homogeneous material, a relatively impermeable membrane, or barrier used in a geotechnical engineering application so as to control fluid migration from a man-made project, structure, or system. In the use of geomembranes as barriers to the transmission of fluids, it is important to recognize that it differs from other liner materials that are porous such as soils and concrete. The transmission of permeating species through geomembranes without holes occurs by absorption of the species in the geomembrane and diffusion through the geomembrane on a molecular basis [1]. Bituminous geomembranes (GBR-B) are mainly composed of a binder (the modified bitumen), a filler (mostly calcite mine is used industrially), and a reinforcement (glass fleece or nonwoven polyester is preferred) as shown in Figure 1.

GBR-Bs are highly resistant to oxidation and UV rays without an antioxidant or stabilizer when compared to polymeric geomembranes (GBR-P). GBR-Ps are widely used in landfills as impermeable liner. Also the viscoelastic behavior of GBR-B allows self-repair of any defect that may occur with time such as strain, puncture, or fracture. Fillers are used in GBR-B with the intent of increasing stiffness and strength and also filling the voids in the hot mixture [2]. The filler is not only natural aggregates such as calcite, but also lime, lignin, sulfur, or ultrathin cut fiber particles which could pass number $200(0.075 \mathrm{~mm})$ sieve [3].

Turkey has $72 \%$ of the world's boron reserves and takes the first place with a reserve of 1.8 million tons. Eskisehir Eti Maden Kurka Boron Works has the largest boron reserve in 


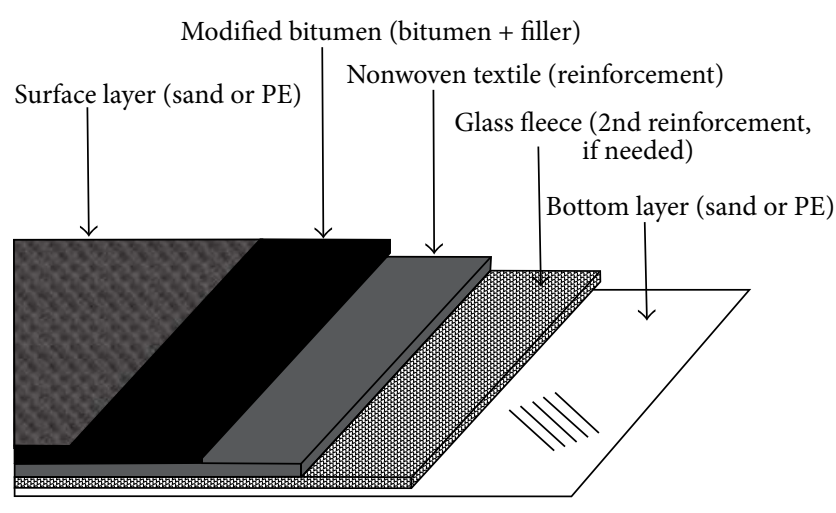

FIGURE 1: Bituminous geomembrane [1].

Turkey with $41 \%$ of the world's boron production. On the other hand, boron minerals have a strategic importance due to their wide range of uses in the manufacture of industrial products including glass, ceramic, textile, detergent, metallurgical, and fire-retardant materials. Thus, 900.000 tons of boron derivative waste are generated during 1 million-ton borax pentahydrate production [4]. Increasing amount of mining wastes, storage, stability, and safety of waste, and air, soil, and water pollution are major environmental issues [5]. Under the circumstances, developing novel products from the waste clay and investigating the utilization areas for waste clay become a necessity.

There have been studies related to utilization of the clay derivative waste and concentrated waste from boron concentrator facilities in various sectors such as cement [611], construction, brick and tile [12-20], and ceramic [21, 22]. Among these various studies, to our best knowledge, utilization of boron waste clay as a filler material has not been studied. Therefore, in this study, boron production waste clay (CW) was used as filler to produce a geosynthetic barrier with bentonite, waste tire (TW), and bitumen. Bentonite and waste tires were used as auxiliary fillers and bitumen was used as the binder.

\section{Materials and Methods}

2.1. Materials. Waste clay samples used in this study were collected from Eti Maden Kirka Boron Works in Eskisehir, Turkey. Basic geotechnical properties of the waste clay were given in Table 1. Grain-size distribution of CW consists of $1.74 \%$ sand, $20.76 \%$ silt, and $77.5 \%$ clay and the determined soil class is high plasticity clay $(\mathrm{CH})$. CEC of the $\mathrm{CW}$ is $55 \mathrm{meq} / 100 \mathrm{~g}$ and this kind of high CEC values denotes that the clay is able to hold more contaminants. According to XRD, XRF, ICP-MS, and FT-IR results, dolomite is the most dominant compound in the $\mathrm{CW}$ followed by magnesium oxide, tincal, and quartz. The specific surface area of the CW is $5.12 \pm 0.1 \mathrm{~m}^{2} / \mathrm{g}$ by BET analysis method. The analyses methods and the details of the properties are available in our previous study [23].

Bitumen is used on the purpose to coalesce and unite the clay particles. The properties of bitumen (penetration
$100 / 150$ at $25^{\circ} \mathrm{C}, 100 \mathrm{~g}, 5 \mathrm{sec}$; softening point $39-47^{\circ} \mathrm{C}$; flash point $230^{\circ} \mathrm{C}$ ), the binder of the hot mixtures, were adopted from Turkish Petroleum Refineries Corporation (TÜPRAŞ), Turkey. Bentonite is generally used in improvement of impermeable compacted clay layers in landfills due to its high swelling potential and low hydraulic conductivity [24]. Bentonite was obtained from a bentonite plant. In this study, it is aimed at utilizing waste tires in landfill sites as a side material using boron waste clay. The particle size of the adopted waste tire samples was less than $1.18 \mathrm{~mm}$. The steel free waste tire $(<1.18 \mathrm{~mm})$ was adopted from a tire recycling plant. Two different reinforcement materials were used, fiberglass tissue also known as glass fleece (CT) and nonwoven polyester $(\mathrm{PK})$, and both were obtained from a geomembrane production plant.

2.2. Geomembrane Production. In the geomembrane production process, bitumen was firstly mixed with auxiliary fillers, bentonite or waste tire within a laboratory mixer at $100^{\circ} \mathrm{C}$. After obtaining a homogenous mixture waste clay was added at certain amounts given in Table 2 and mixed for 45 minutes. In addition to geomembrane samples including bentonite or waste tire, neat samples including only CW were also prepared.

After mixing, hot mixtures were extruded into strips by using a lab-scale corotating twin screw extruder ( $L / D: 40)$ followed by die casting $(2 \mathrm{~mm} \times 100 \mathrm{~mm})$. The temperatures of the various barrel elements were set in the ranges 100$130^{\circ} \mathrm{C}$ (bitumen introduction) and $38-52^{\circ} \mathrm{C}$ (extruder exit). Depending on the ingredients amount, the apparent fluidity of hot mixtures differed from each other. In order to obtain optimum product with stabile strip shape and no visible deformations such as puncture, tearing, or ruffle, different heating profiles were constituted for each mixture.

The extruded strips were then passed on a conveyor belt at a speed of $1 \mathrm{rpm}$. Two different reinforcement materials were used, fiberglass tissue also known as glass fleece (CT) and nonwoven polyester (PK). When the optimum profile was obtained, reinforcement material was placed on the binder mixture in strip shape and another layer of strip was placed on the reinforcement and pressed. Thus, both sides of the reinforcement material were covered with bituminous mixture (Figure 2).

2.3. Analyses Performed on GBR-B. According to the Turkish Standard of "TS EN 13493: Geosynthetic barriersCharacteristics required for use in the construction of solid waste storage and disposal sites," thickness (TS EN 18491), mass per unit area (TS EN 1849-1), tensile strength (TS EN 12311-1), elongation at yield (TS EN 12311-1), and hydraulic conductivity (TS EN 14150) tests were applied to geomembranes with/without reinforcements to see the effect of reinforcements.

The tensile properties are the most critical mechanical properties of geomembranes since there are a range of tensile forces that can act on the geomembrane during installation and service. Also it is misleading to assume that if a geomembrane material has a high elongation at break, it 
TABLE 1: Geotechnical properties of CW.

\begin{tabular}{|c|c|c|c|c|c|c|c|c|}
\hline $\begin{array}{l}\text { Water } \\
\text { content, \% }\end{array}$ & $\begin{array}{l}\text { Specific } \\
\text { weight, } \\
\mathrm{g} / \mathrm{cm}^{3}\end{array}$ & $\begin{array}{c}\text { Liquid limit, } \\
\%\end{array}$ & $\begin{array}{c}\text { Plastic limit, } \\
\%\end{array}$ & $\begin{array}{l}\text { Plasticity } \\
\text { index, \% }\end{array}$ & $\begin{array}{l}\text { Optimum water } \\
\text { content, } \%\end{array}$ & $\begin{array}{c}\text { Unconfined } \\
\text { compressive } \\
\text { strength, } \mathrm{kg} / \mathrm{cm}^{2}\end{array}$ & $\begin{array}{c}\text { Hydraulic } \\
\text { conductivity, } \\
\mathrm{m} / \mathrm{s}\end{array}$ & $\begin{array}{c}\text { Swelling } \\
\text { potential, } \\
\% \\
\end{array}$ \\
\hline 39.2 & 2.77 & 58 & 30 & 28 & 33 & 2.16 & $3.5 \times 10^{-11}$ & 10.4 \\
\hline
\end{tabular}

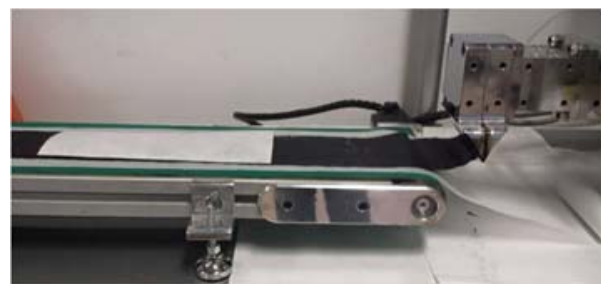

(a)

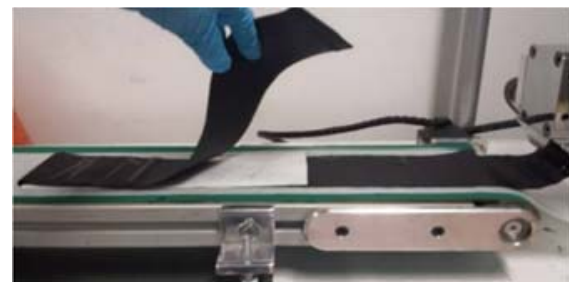

(b)

FIGURE 2: Geomembrane production with lab-scale extruder.

TABLE 2: BTM/CW, BTM/CW/BNT, and BTM/CW/TW specimens and proportions.

\begin{tabular}{lcccc}
\hline Specimen code & BTM, \% & CW, \% & BNT, \% & TW, \% \\
\hline BTM30CW70 & 30 & 70 & - & - \\
BTM40CW60 & 40 & 60 & - & - \\
BTM50CW50 & 50 & 50 & - & - \\
BTM40CW50BNT10 & 40 & 50 & 10 & - \\
BTM40CW52BNT8 & 40 & 52 & 8 & - \\
BTM40CW55BNT5 & 40 & 55 & 5 & - \\
BTM40CW50TW10 & 40 & 50 & - & 10 \\
BTM40CW52TW8 & 40 & 52 & - & 8 \\
BTM40CW55TW5 & 40 & 55 & - & 5 \\
\hline
\end{tabular}

BTM: bitumen; CW: waste clay; BNT: bentonite; TW: waste tire All numbers in specimen codes represent the percentage of material at its left in the mixture.

has high survivability in service. Elongation at yield of the geomembrane should be investigated instead of elongation at break because after yield elongation point, deformation is irreversible. For instance, high density polyethylene (HDPE) has an elongation at break value of $700 \%$ but exhibits a distinct yield point at $12 \%$ strain [1]. According to the tensile and elongation properties, one of the BTM/CW, BTM/CW/BNT, and BTM/CW/TW geomembranes was selected to apply hydraulic conductivity test (Figure 3 ).

2.4. Exposure to Leachate. Leachate tests were applied to the most promising geomembrane sample determined by the analyses according to TS EN 13493. Geomembrane sample was exposed to distilled water (DW), municipal solid waste landfill leachate (L-MSW), and hazardous waste landfill leachate (L-HW). L-MSW was collected from a municipal solid waste landfill and L-HW was collected from İzmit Waste and Residue Treatment Incineration Recycling Co. (IZAYDAŞ). The test arrangement constituted for geomembranes exposure to leachate (Figure 4(a)) included a hydraulic conductivity test cell (Figure 4(b)) which was composed of two parts $(D: 50 \mathrm{~mm})$ holding to each other by clamping for housing the geomembrane sample. In Figure 4(a), 1 bar of pressure was constantly applied on the leachate column to sustain the 1-bar fluid pressure in test cell. The plastic bottle on the bottom is placed for collecting leachate sample from the exit stream of the cell in case of any leaching occurrence. The leachate exposure test lasted for 35 days. SEM analysis was performed to examine the structural changes on the surface of geomembrane specimen due to exposure to leachates by using Phenom ProX SEM. Before the analysis, in order to prevent electrical charging, geomembrane was covered with gold for 40 seconds under the presence of Argon gas. During the analysis, 300, 500, and 1000x zoomed SEM images were obtained for each geomembrane and the appropriate 2 images in all 3 were chosen for consideration.

\section{Results and Discussion}

Results of thickness, mass per unit area, tensile strength, and elongation at yield analyses performed on geomembrane samples with/without reinforcement are given in Table 3 . A commercial geomembrane was also tested in order to compare the results of produced geomembranes.

According to Table 3, geomembrane samples had thickness values between 2.5 and $3.7 \mathrm{~mm}$. These thickness values are in the range of 2 to $5 \mathrm{~mm}$ given by the literature [1]. Produced samples had mass per unit area values between 3.6 and $5.4 \mathrm{~kg} / \mathrm{m}^{2}$. Geomembranes with mass per unit area above $0.5 \mathrm{~kg} / \mathrm{m}^{2}$ are considered as heavyweight membranes since this specification depends on density of the reinforcement and the filler [1].

Tensile strength of the geomembrane samples without reinforcements decreases with increasing bitumen content; in other words, tensile strength increases with increasing waste clay content.

Bentonite addition improved neither tensile strength nor elongation of geomembrane. At constant bitumen content, decreasing bentonite content and increasing waste clay 

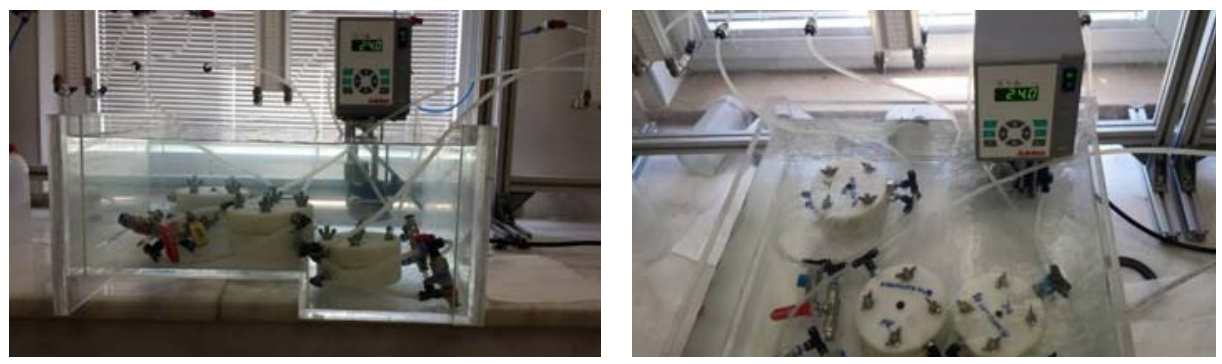

FIGURE 3: Hydraulic conductivity test arrangement.

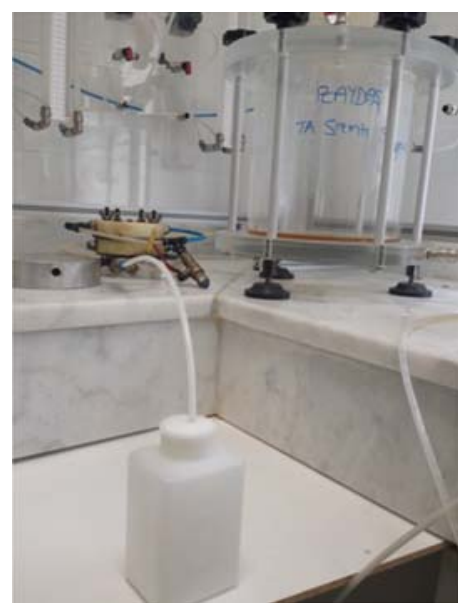

(a)

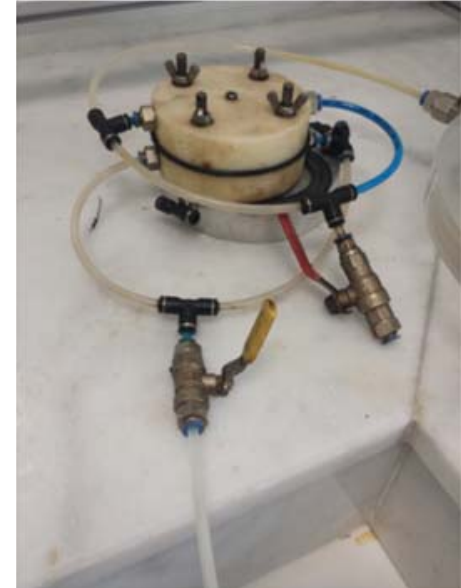

(b)

FIGURE 4: Leachate test arrangement: (a) leachate column; (b) test cell.

content affected tensile strength values of geomembrane negatively.

Waste tire addition improved tensile strength when bitumen/waste clay/waste tire mixtures were examined. At constant bitumen amount, tensile strength of the geomembrane increased with increasing waste tire amount. So with the intent of utilizing waste tires, waste tire could be used in geomembrane materials as modifier of bitumen.

Glass fleece reinforced geomembranes, in other words the CT-specimens, had relatively higher tensile strength values. However elongation values were in the range of 5$8 \%$ which was very low when compared to the commercial geomembrane.

The highest elongation belonged to PK-BTM30CW70 and PK-BTM50CW50, where nonwoven polyester reinforcement is already known to have a beneficial usage in geomembranes due to its high yield elongation. Tensile strength of PK-specimens was also higher than the commercial bituminous geomembrane. Therefore, $\mathrm{PK}$ (nonwoven polyester) was considered as the most appropriate reinforcement material. Since all specimens with PK had favorable tensile strength and elongation values, the one with highest waste clay content among BTM/CW, BTM/CW/BNT, and BTM/CW/TW groups was selected for hydraulic conductivity test application.
Hydraulic conductivity test was performed with PK-BTM30CW70, PK-BTM40CW55BNT5, and PKBTM40CW55TW5. The hydraulic conductivity test results were $3.6 \times 10^{-6}, 2.2 \times 10^{-5}$, and $1.0 \times 10^{-5} \mathrm{~m}^{3} / \mathrm{m}^{2} /$ day, respectively, while the hydraulic conductivity of commercial geomembrane was $10^{-6} \mathrm{~m}^{3} / \mathrm{m}^{2} /$ day. PK-BTM30CW70 had the closest value to commercial geomembranes' value; hence leachate exposure tests were performed with only that specimen.

3.1. Exposure to Leachate Results. Leachate exposure tests were carried on with PK-BTM30CW70 for 35 days. Meanwhile, leaching of any water sample through geomembrane was not observed; the outlet tubes and sample bottles were both empty at the end of the experiment. This result was a proof of considerably low hydraulic conductivity of the produced geomembrane. SEM analysis was performed on uncured geomembrane (Figure 5) and geomembrane samples exposed to DW (Figure 6), L-MSW (Figure 7), and L-HW (Figure 8).

SEM images of uncured geomembrane show a solid structure without any scratch, puncture, or gaps. Here, waste clay seems to be distributed homogenously in the mixture and size of waste clay particles is in the range of $10-20 \mu \mathrm{m}$. 
TABle 3: Physical properties of all specimens and constituents.

\begin{tabular}{|c|c|c|c|c|c|}
\hline Reinforcement state & Specimen & $\begin{array}{l}\text { Thickness } \\
(\mathrm{mm})\end{array}$ & $\begin{array}{l}\text { Mass per unit } \\
\text { area }\left(\mathrm{kg} / \mathrm{m}^{2}\right)\end{array}$ & $\begin{array}{c}\text { Tensile } \\
\text { force }(\mathrm{kN})\end{array}$ & $\begin{array}{c}\text { Elongation } \\
(\%)\end{array}$ \\
\hline \multirow{9}{*}{ Without reinforcement } & BTM30CW70 & 1.4 & 2.2 & 0.0033 & 20 \\
\hline & BTM40CW60 & 1.3 & 2.0 & 0.0022 & 20 \\
\hline & BTM50CW50 & 1.2 & 1.8 & 0.0010 & 20 \\
\hline & BTM40CW50BNT10 & 1.4 & 2.3 & 0.0010 & 20 \\
\hline & BTM40CW52BNT8 & 1.4 & 2.5 & 0.0012 & 20 \\
\hline & BTM40CW55BNT5 & 1.5 & 2.7 & 0.0013 & 20 \\
\hline & BTM40CW50TW10 & 1.5 & 2.3 & 0.0029 & 50 \\
\hline & BTM40CW52TW8 & 1.5 & 2.5 & 0.0022 & 30 \\
\hline & BTM40CW55TW5 & 1.7 & 2.6 & 0.0022 & 32 \\
\hline \multicolumn{6}{|l|}{ With reinforcement } \\
\hline \multirow{8}{*}{ Glass fleece } & Glass fleece & 0.25 & 0.044 & 0.1045 & 1.4 \\
\hline & CT-BTM30CW70 & 3.2 & 4.4 & 0.5152 & 7 \\
\hline & CT-BTM40CW60 & 2.7 & 4.0 & 0.6386 & 7 \\
\hline & CT-BTM50CW50 & 2.8 & 3.6 & 0.4606 & 7 \\
\hline & CT-BTM40CW50BNT10 & 3.0 & 5.4 & 0.5520 & 7 \\
\hline & CT-BTM40CW52BNT8 & 3.1 & 4.9 & 0.5735 & 8 \\
\hline & CT-BTM40CW55BNT5 & 3.2 & 4.6 & 0.6000 & 7 \\
\hline & CT-BTM40CW50TW10 & 3.2 & 4.6 & 0.3104 & 5 \\
\hline \multirow{12}{*}{ Nonwoven polyester } & CT-BTM40CW52TW8 & 3.7 & 5.0 & 0.5606 & 7 \\
\hline & CT-BTM40CW55TW5 & 3.6 & 5.2 & 0.4860 & 7 \\
\hline & Nonwoven polyester & 0.5 & 0.148 & 0.3885 & 40 \\
\hline & PK-BTM30CW70 & 3.2 & 4.5 & 0.4928 & 68 \\
\hline & PK-BTM40CW60 & 2.5 & 4.1 & 0.4213 & 57 \\
\hline & PK-BTM50CW50 & 3.0 & 3.7 & 0.4830 & 68 \\
\hline & PK-BTM40CW50BNT10 & 3.1 & 4.7 & 0.4061 & 53 \\
\hline & PK-BTM40CW52BNT8 & 3.4 & 5.0 & 0.4624 & 62 \\
\hline & PK-BTM40CW55BNT5 & 3.4 & 5.5 & 0.4964 & 67 \\
\hline & PK-BTM40CW50TW10 & 3.2 & 4.7 & 0.5088 & 35 \\
\hline & PK-BTM40CW52TW8 & 3.5 & 5.1 & 0.4935 & 59 \\
\hline & PK-BTM40CW55TW5 & 3.6 & 5.3 & 0.4986 & 59 \\
\hline \multicolumn{2}{|c|}{ Commercial geomembrane } & 3.2 & 3.6 & 0.4032 & 75 \\
\hline
\end{tabular}

BTM: bitumen; CW: waste clay; BNT: bentonite; TW: waste tire; PK: nonwoven polyester; CT: glass fleece

All numbers in specimen codes represent the percentage of material at its left in the mixture.

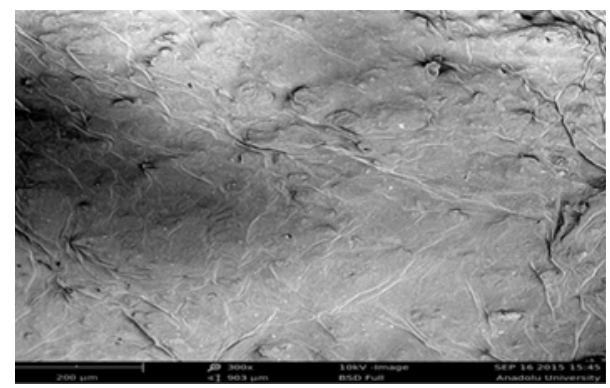

(a)

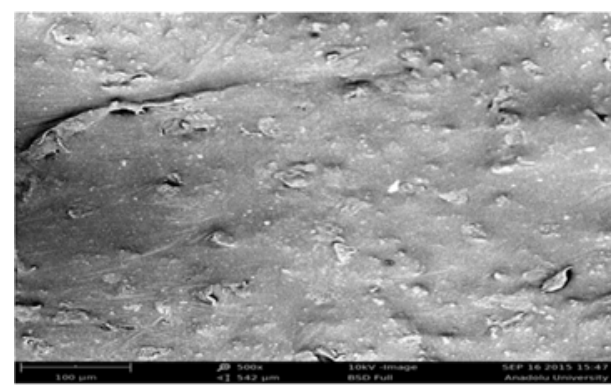

(b)

FIgURE 5: SEM images of uncured PK-BTM30CW70: (a) 300x; (b) 500x. 


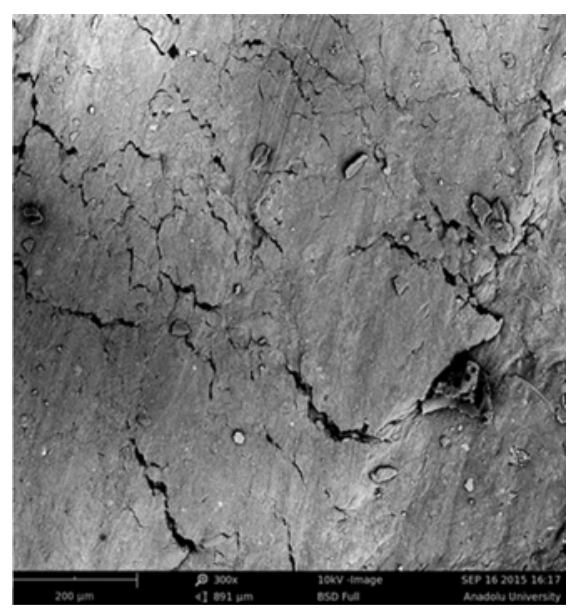

(a)

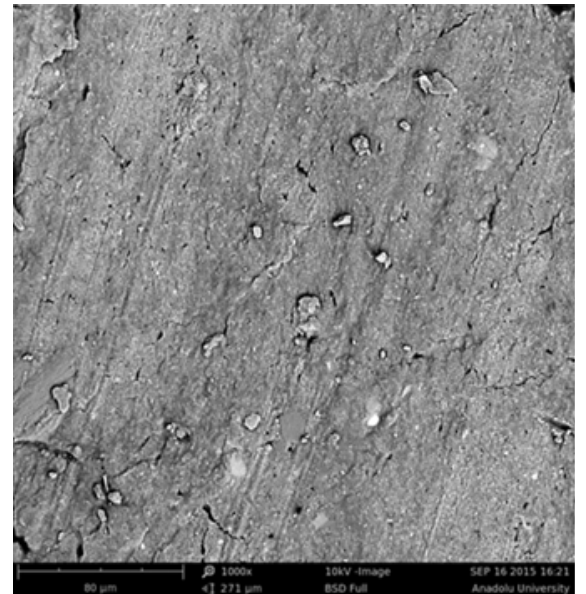

(b)

Figure 6: SEM images of PK-BTM30CW70 exposed to DW: (a) 300x; (b) 1000x.

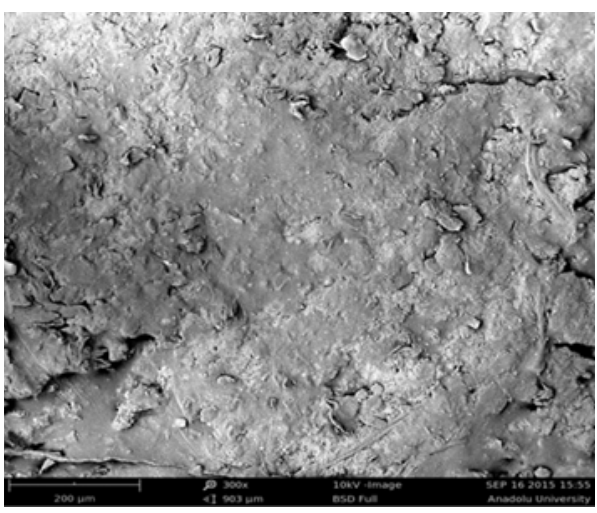

(a)

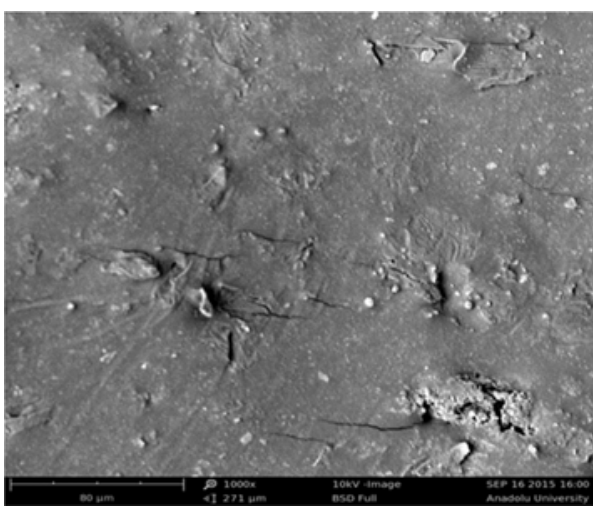

(b)

Figure 7: SEM images of PK-BTM30CW70 exposed to L-MSW: (a) 300x; (b) 1000x.

Geomembrane sample exposed to distilled water had some scratches with maximum length of $200 \mu \mathrm{m}$ and a small amount of waste clay was released from the bitumen and reached the surface. Geomembrane exposed to L-MSW had $200 \mu \mathrm{m}$ scratches and also fractional punctures with the length range $10-20 \mu \mathrm{m}$. Geomembrane exposed to L-HW had a relatively more defective image with punctures at length of 20-50 $\mu \mathrm{m}$. Clay particles that reached surface were observed more in those images. The punctures are claimed to be a result of a certain amount of waste clay released from the bitumen when the geomembrane gets in contact with any kind of water. However those defects were limitative on the top surface of the geomembrane. Additionally, any effect on the bottom was not expected since no leaching was observed.

\section{Conclusion}

In this study, waste clay generated during boron derivatives production was mixed with bitumen, bentonite, and waste tire and these mixtures were used to cover up reinforcement materials (nonwoven polyester and glass fleece). Among all produced geomembrane samples, according to thickness, mass per unit area, tensile strength, and elongation results, the samples were eliminated by comparing to a commercial geomembrane and only three samples (PK-BTM30CW70 (nonwoven polyester, 30\% bitumen, 70\% waste clay), PKBTM40CW55TW5 (nonwoven polyester, 40\% bitumen, 55\% waste clay, and 5\% waste tire), and PK-BTM40CW55B5 (nonwoven polyester, $40 \%$ bitumen, 55\% waste clay, and $5 \%$ bentonite)) were used to apply hydraulic conductivity test. PK-BTM30CW70 was determined as the optimum geomembrane with the lowest hydraulic conductivity. Therefore leachate exposure tests were performed with PKBTM30CW70 and distilled water, municipal solid waste leachate, and hazardous waste leachate. During the experiments, leaching did not occur, but SEM analysis comparison of geomembranes exposed to leachate showed increasing defectives such as scratches and punctures. Those structural defects did not affect the impermeability of geomembrane.

In terms of tensile strength, elongation, and hydraulic conductivity, boron waste clay could be used in geomembrane production instead of calcite in order to lower the cost 


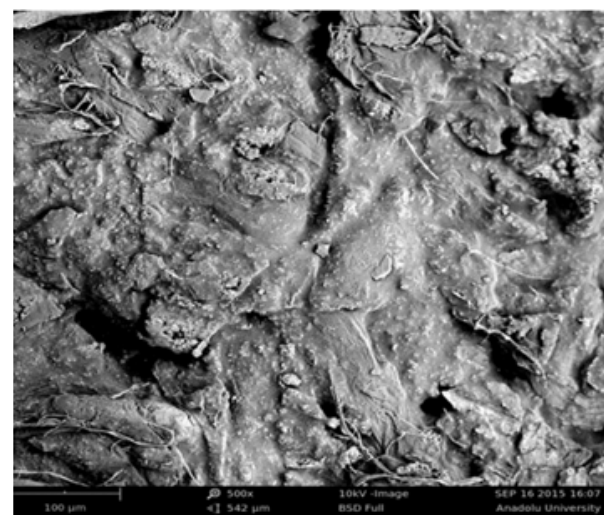

(a)

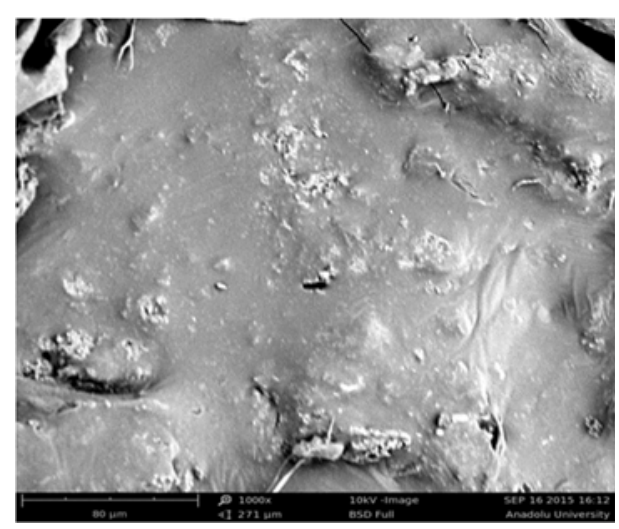

(b)

FIGURE 8: SEM images of PK-BTM30CW70 exposed to L-HW: (a) 500x; (b) 1000x.

while leading up to utilize waste clay of 900,000 tons/year generated at boron enterprises in Turkey. The optimum geomembrane produced is appropriate to use in landfills in means of the applied test results. As a conclusion, this study has an importance from the point of sustainable waste management principles with its aim to produce an innovative material by using waste materials.

\section{Conflict of Interests}

The authors declare that there is no conflict of interests regarding the publication of this paper.

\section{Acknowledgments}

This study was supported by TUBITAK (the Scientific and Technological Research Council of Turkey) under Grant no. 113 Y122 and Anadolu University Scientific Research Projects Commission under Grant no. 1301F037.

\section{References}

[1] J. Scheirs, A Guide to Polymeric Geomembranes, Wiley Series in Polymer Sciences, John Wiley \& Sons, Hoboken, NJ, USA, 2009.

[2] A. Geçkil, Effect of graine tires on low temperature and elasticity behavior of bitumen and hot bitumen mixtures [M.S. thesis], Firat University, Elâzı ̆̆, Turkey, 2013 (Turkish).

[3] V. Antunes, A. C. Freire, L. Quaresma, and R. Micaelo, "Influence of the geometrical and physical properties of filler in the filler-bitumen interaction," Construction and Building Materials, vol. 76, pp. 322-329, 2015.

[4] "Eti Mine works general management," Boron Sector Report, Technical Report, 2010, (in Turkish).

[5] M. Karadeniz, Mineral Enrichment Tests Residue Environmental Effects/Precautions, Directorate of Mineral Research and Exploration, Department of Mineral Analysis and Technology, 1996 (Turkish).

[6] İ. Kula, A. Olgun, V. Sevinc, and Y. Erdogan, "An investigation on the use of tincal ore waste, fly ash, and coal bottom ash as Portland cement replacement materials," Cement and Concrete Research, vol. 32, no. 2, pp. 227-232, 2002.
[7] M. Özdemir and N. U. Öztürk, "Utilization of clay wastes containing boron as cement additives," Cement and Concrete Research, vol. 33, no. 10, pp. 1659-1661, 2003.

[8] R. Boncukçuoğlu, M. T. Yilmaz, M. M. Kocakerim, and V. Tosunoğlu, "Utilization of trommel sieve waste as an additive in Portland cement production," Cement and Concrete Research, vol. 32, no. 1, pp. 35-39, 2002.

[9] Ş. Targan, Y. Erdoğan, A. Olgun, B. Zeybek, and V. Sevinç, "Utilization of clinker, bentonite and colemanite wastes in cement production," in Proceedings of the 1st International Boron Symposium, pp. 259-266, Kütahya, Turkey, October 2002.

[10] M. E. Akbulut, Examination of properties of boron waste added cement in third component conditions [M.S. thesis], Afyon Kocatepe University, Afyonkarahisar, Turkey, 2009 (Turkish).

[11] A. Uğurlu, Effect of waste generated at boron production usage with pozzolanic materials on cement production [Ph.D. thesis], Eskișehir Osmangazi University, Eskişehir, Turkey, 2009 (Turkish).

[12] T. Kavas, "Use of boron waste as a fluxing agent in production of red mud brick," Building and Environment, vol. 41, no. 12, pp. 1779-1783, 2006.

[13] İ. Demir and M. Orhan, "Utilization of boron waste in the production building materials," in I. International Boron Symposium Proceedings Book, pp. 235-239, Kütahya, Turkey, 2002.

[14] N. Ediz and H. Yurdakul, "Utilization of waste generated at Etibor Kurka Borax Works DSM as filler in wall tile production," in 1st International Boron Symposium Proceedings Book, pp. 246-249, Dumlupınar University, Kütahya, Turkey, 2002.

[15] B. Karasu, G. Kaya, and H. Yurdakul, "Effect of the Etibor Kirka Borax Company's concentration and derivation wastes on the properties of wall tile body," in Proceedings of the 1st International Boron Symposium, pp. 224-228, Kütahya, Turkey, October 2002.

[16] T. Kavas and G. Önce, “The usage capacity of Etibor Kırka Borax Company's wastes in the production of structural bricks as a flax material," in Proceedings of the of the 1st International Boron Symposium, pp. 219-223, Kütahya, Turkey, 2002.

[17] Ö. F. Emrullahoğlu and C. B. Emrullahoğlu, "Effect of borax waste generated at Etibor Kurka on flor tile," in I. International Boron Symposium Proceedings Book, pp. 213-218, Kütahya, Turkey, 2004.

[18] T. Uslu and A. I. Arol, "Use of boron waste as an additive in red bricks," Waste Management, vol. 24, no. 2, pp. 217-220, 2004. 
[19] S. Kurama, A. Kara, and H. Kurama, "Investigation of borax waste behaviour in tile production," Journal of the European Ceramic Society, vol. 27, no. 2-3, pp. 1715-1720, 2007.

[20] T. Batar, S. Köksal, and E. Yersel, "Production of boron waste, waste paper and pearlite added plaster and its characterization," Ekoloji, vol. 72, pp. 45-53, 2009 (Turkish).

[21] A. Christogerou, T. Kavas, Y. Pontikes, S. Koyas, Y. Tabak, and G. N. Angelopoulos, "Use of boron wastes in the production of heavy clay ceramics," Ceramics International, vol. 35, no. 1, pp. 447-452, 2009.

[22] A. Olgun, Y. Erdogan, Y. Ayhan, and B. Zeybek, "Development of ceramic tiles from coal fly ash and tincal ore waste," Ceramics International, vol. 31, no. 1, pp. 153-158, 2005.

[23] D. Ulutas, E. Bayrakci, Z. Cokaygil, A. Ozkan, Y. Guney, and M. Banar, "Geotechnical, chemical and structural characterization of waste clay from boron production," Athens Journal of Technology Engineering, vol. 1, no. 3, pp. 171-179, 2014.

[24] M. H. Gleason, D. E. Daniel, and G. R. Eykholt, "Calcium and sodium bentonite for hydraulic containment applications," Journal of Geotechnical Engineering, vol. 123, no. 5, pp. 438-445, 1997. 

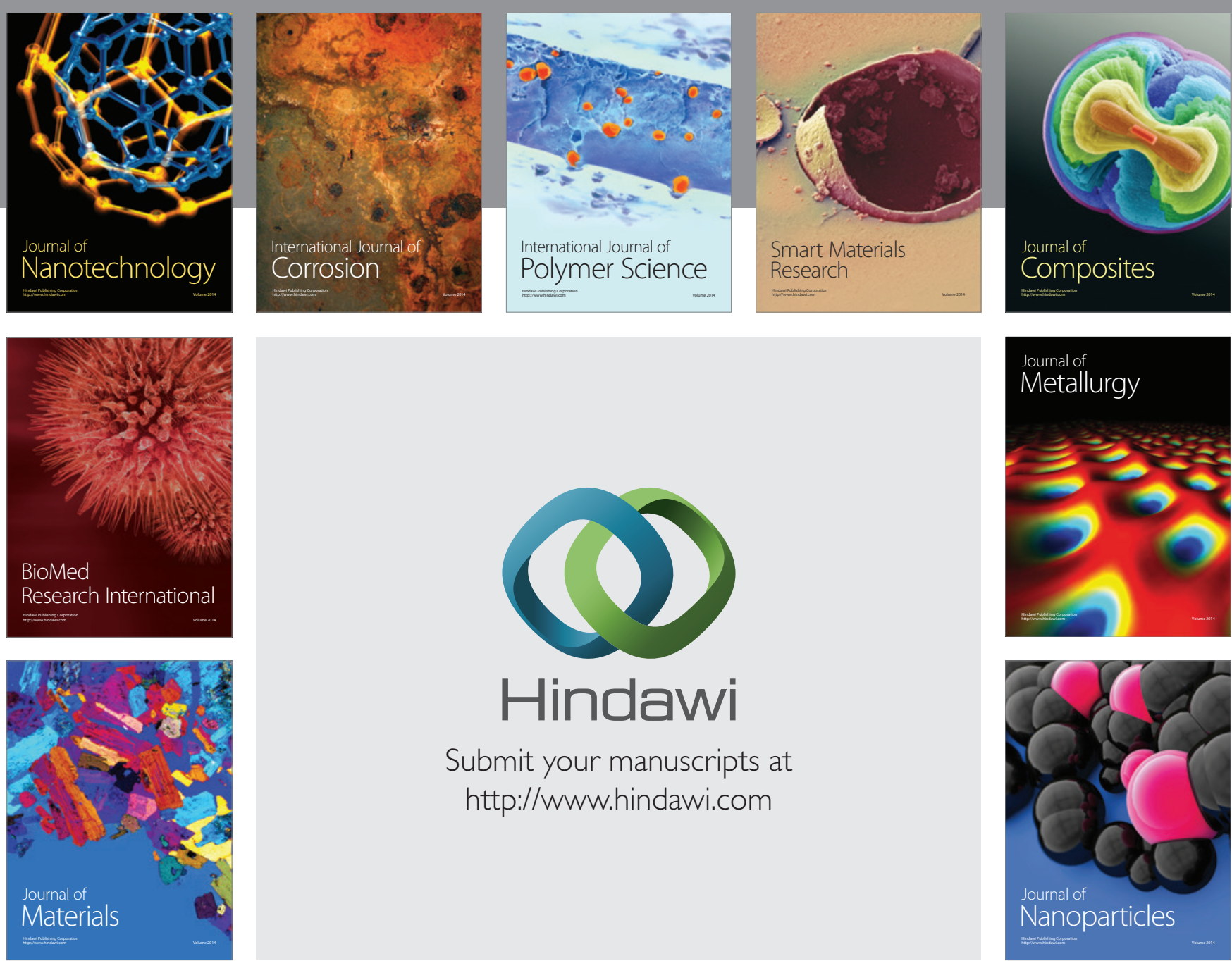

\section{Hindawi}

Submit your manuscripts at

http://www.hindawi.com

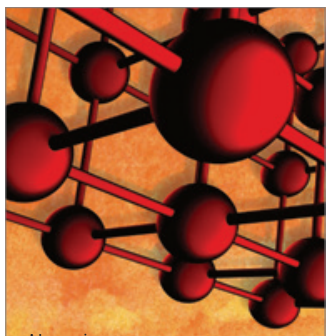

Materials Science and Engineering
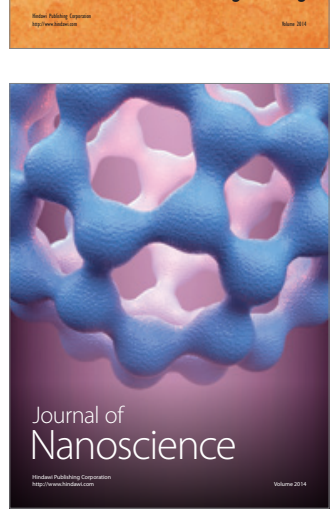
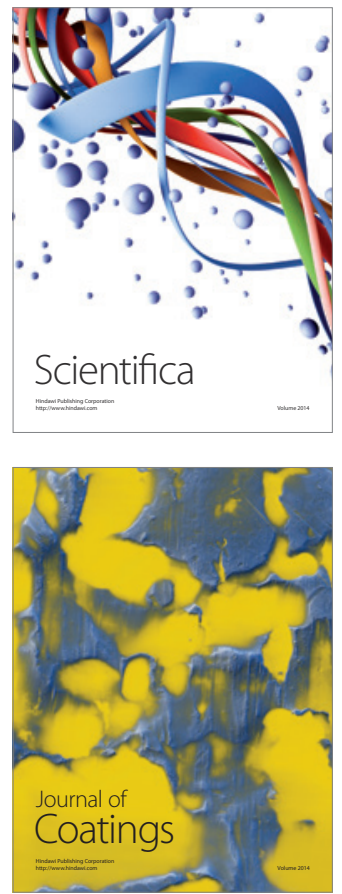
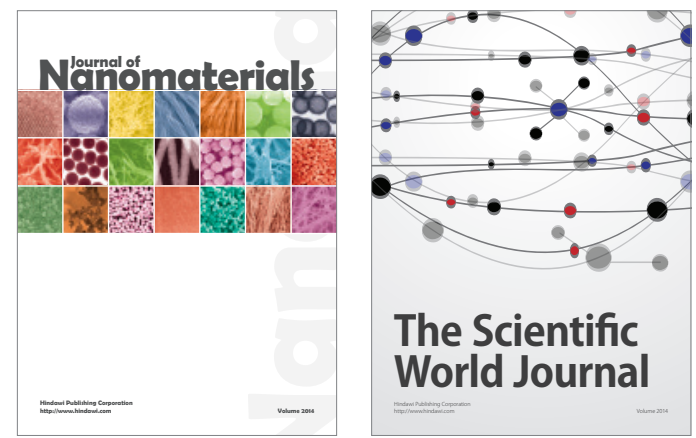

The Scientific World Journal
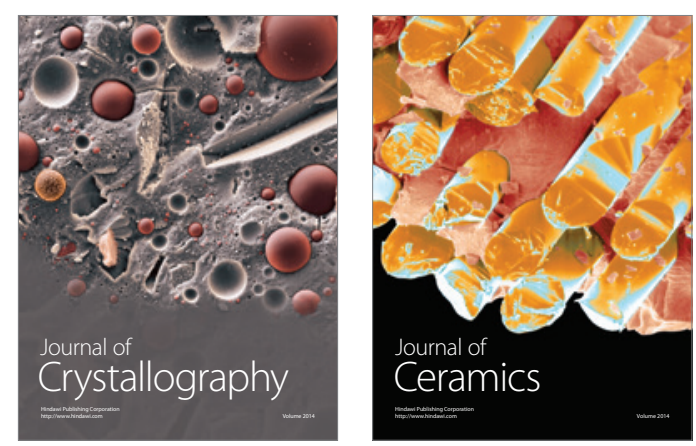
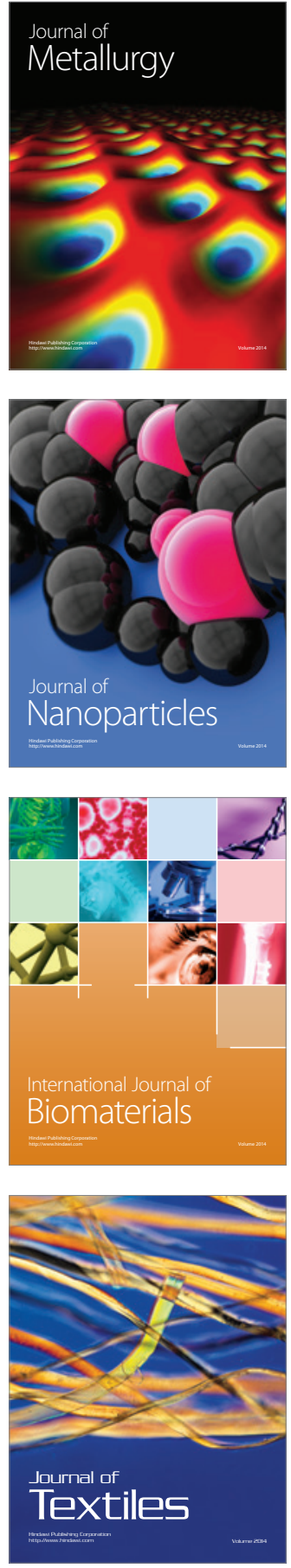